\title{
Service Quality, Satisfaction and Behavioral Intentions Aspects across Different States in Retailing
}

\author{
Dr. Ajmer Singh \\ Faculty in Marketing, Kurukshetra University Regional Centre \\ Jind, Haryana, India \\ E-mail: ajmer.singh@kuk.ac.in
}

Received: June 30, 2014 Accepted: July 12, 2014

doi:10.5296/ber.v4i2.5979 URL: http://dx.doi.org/10.5296/ber.v4i2.5979

\begin{abstract}
This study is carried out to examine the service quality, customer satisfaction and behavioral intentions aspects across the retail outlets in India. This study is being carried out from three states of India which are Delhi, Haryana (Gurgaon \& Faridabad) and Uttar Pradesh (Noida \& Ghaziabad) are being selected to carry out this study. In this study a total of 600 customers are being chosen and 200 customers are selected from each state of India. Probability sampling method is chosen for collecting the data. Finally 540 filled in questionnaires are collected from the market. The data analysis is done by descriptive statistics, mean and one-way ANOVA. Finally there is found significant difference among the many aspects of service quality, customer satisfaction and behavioral intentions in retail outlets. For service quality in retail outlets, the scale developed by Dhabolkar, Thorpe and Rentz being used in the study. Various dimensions of customer satisfaction and behavioral intentions are found by reviewing of related literatures. This study makes the implications for the managers in these states to improve upon the service quality, customer satisfaction and behavioral intentions in retail outlets. In this study a response rate of $90 \%$ is achieved from the data collected. Finally customers are also allowed to provide their suggestions for further improvements in the aspects of service quality, customer satisfaction as well as behavioral intentions like purchasing decisions, complaining decisions, recommendation behavior etc. This research is important to understand the difference in the various dimensions of service quality as well as customer satisfaction and recommending and purchasing differences across the different localities in a country.
\end{abstract}

Keywords: Service quality, Satisfaction, Purchasing intention, Recommending behavior, Complaining behaviour, Product quality etc. 


\section{Introduction}

\subsection{Retailing Perspectives in India}

Retailing in India is growing at a very fast rate. Retailing is contributing to Indian GDP more than what the banking and insurance sector does together. As we know Indian population is moving towards the big cities in the country. This is increasing the space for expansion for Indian retail. There are large numbers of big retailers like Reliance Fresh, Big Bazaar, Ebony, Spencer's, Westside etc. are having large number of stores in Delhi as well as in the nearby areas of Delhi. Organized form of retailing is spreading its scope Delhi as well as in the around areas of Delhi at a very fast rate. India is having a large middle-class income population with rising incomes and this middle income group is being driven by price-value evaluation in their consumption pattern (Indian Retail Report, 2009). Indian Government has recently allowed $100 \%$ FDI in cash and carry operations and $51 \%$ in single brand retail in our country (Indian Retail Report, 2009). According to a study by Mckinsey suggested that Indian consumer market will become the world largest fifth market by the year 2025. There is an increase in the disparity of Indian Income and richer are becoming more and richer and poorer are becoming more and poorer in the country. Service quality, customer satisfaction and behavioral Intentions are very essential for achieving the growth in the retail stores. Customer loyalty is an important factor in retailing sector (Park and Kim, 2003; Yang and Peterson, 2004). Loyalty brings profitability to the retailers by decreasing costs and increasing commitment to the retailers (Reichheld et al., 2000). Customer service is very important for the business success of the company (Taguiri and Davis, 1992). In our country organized retailing is growing at a very fast rate. It is growing at a rate of $35 \%$ year on year basis and organized retailing is existing around $5 \%$ of total Indian retailing. Organized retailing is growing in all the spheres of Indian retailing either it may be consumer goods, electronic goods, shopping goods etc. In retail stores, price and quality are one of the important factors which determine the future growth prospects and profits of retailers in any country ((Hardesty, Bearden, and Carlson 2007; Hardesty and Bearden 2003). It was also found that a customer is ready to pay the price on the basis of the value of the product and it decides his/her purchasing decision (Netemeyer et al. 2004). Hence quality becomes an important gradient for customer attraction as well as customer purchasing decision in the store. For attracting the large number of customers in the store, quality upgradation becomes an important criterion for the retail stores in the market. Hence it becomes very important to understand the level of customer service quality, satisfaction and behavioral intentions of the store.

\section{Review of Related Literature}

From the review of literature it is found that service quality is having a positive impact on customer satisfaction (Singh, Ajmer; 2013). It was also found that service quality is having a strong impact on behavioral intentions of the retail store, which may include purchasing decisions, complaining behavior, retention behavior etc. (Singh, Ajmer; 2012). Further research suggests in the aspects of service quality, customer satisfaction and behavioral intentions shows a significant difference among the various retail formats like hypermarket, supermarket and departmental stores (Singh, Ajmer; 2013). From the review of literature, it is 
found that service quality is showing its impact on the financial performance of the organization (Greising, 1994; Rust et al., 1995), as well as service quality is showing its impact on consumer satisfaction

(Spreng et al., 1996), and switching behaviour (Keaveney, 1995), and behavioral Intentions (Boulding et al., 1993; Cronin and Taylor, 1992) in the company. It is also found that service quality, customer satisfaction and behavioral intentions differ from place to place and expectations and perceptions differ in these aspects. So it becomes evident to check these aspects across the different states.

\section{Research Methodology}

This study is carried out in the three states of India. These three states are Delhi, Haryana (Gurgaon \& Faridabad) and U.P. (Noida \& Ghaziabad). These states are selected because of large spread of organized retailing among these states. A total sample size of 600 customers are chosen from these states and it is further divided into 200 customers for each state $\mathrm{n}$ India. Seven stores from organized retailing are chosen from these areas. Multistage sampling method is being adopted to collect the data from these states. Finally 540 filled-in questionnaires are collected from these states. It gave a response rate of $90 \%$ in total. The collected data was further analyzed through various statistical methods like descriptive statistics, one-way Anova, mean, sum; percentages are being used to analyze the data in the study.

\section{Data Analysis and Data Interpretation}

\subsection{Descriptive Statistics of Data}

Final data analysis is done with the help of various statistical methods like descriptive statistics like mean, average, as well as one-way Anova is also used in the study.

Table 1. Across Various Demographic Characteristics

\begin{tabular}{|c|c|c|c|c|c|}
\hline Statistics & Your Age & Gender & Education level & Monthly Income & Marital Status \\
\hline 540 & 540 & 540 & 540 & 540 & 540 \\
\hline
\end{tabular}

From the above table 1, it is found that there 540 respondents from which data is collected and the above table is showing a representation of the data among the different demographic variables.

Table 2. Across Various States

\begin{tabular}{|l|c|c|c|}
\hline & Frequency & Percentage & Cumulative Percentage \\
\hline Delhi & 184 & 34.1 & 34.1 \\
\cline { 2 - 4 } Haryana & 180 & 33.3 & 67.4 \\
\cline { 2 - 4 } U.P. & 176 & 32.6 & 100.0 \\
\cline { 2 - 4 } Total & 540 & 100.0 & \\
\hline
\end{tabular}

From the above table 2, it is found that population is distributed among the three states which are Delhi, Haryana (Gurgaon \& Faridabad) and U.P. (Noida \& Ghaziabad). A total sample size 
of 540 Respondents are chosen from these three states. It is found that $184(34 \%)$ respondents belong to Delhi, $180(33.3 \%)$ respondents are from Haryana and $176(32.6 \%)$ from U.P. This shows the respondents distribution across the three states of India.

Table 3. Across Various Age Groups

\begin{tabular}{|l|r|r|r|}
\hline & Frequency & Percentage & Cumulative Percentage \\
\hline 20-to-25 years & 138 & 25.6 & 25.6 \\
\cline { 2 - 4 } 25-to-35 years & 230 & 42.6 & 68.1 \\
\cline { 2 - 4 } 35-to-45 years & 84 & 15.6 & 83.7 \\
\cline { 2 - 4 } $\begin{array}{l}\text { Above 45 years } \\
\text { Total }\end{array}$ & 88 & 16.3 & 100.0 \\
\cline { 2 - 4 } & 540 & 100.0 & \\
\hline
\end{tabular}

From the table 3 , it is found that 230 respondents are belonging to 25 -to-35 years of age out of total 540 respondents. It is further followed by 138 respondents in the age category of 20 -to- 25 years. From the table it is also found that 88 people are above 45 years of age. So from the above analysis, it can be suggested that most of the respondents are falling in the age groups of 25-to-35 years of age.

Table 4. Marital Status

\begin{tabular}{|l|c|c|c|}
\hline & Frequency & Percentage & Cumulative Percentage \\
\hline Male & 343 & 63.5 & 63.5 \\
\cline { 2 - 4 } Female & 197 & 36.5 & 100.0 \\
\cline { 2 - 4 } Total & 540 & 100.0 & \\
\hline
\end{tabular}

In the table number 4 , it is found that there are 540 respondents in the table. It is found that there are 343 female and 197 male in the total sample. Hence from this we can say that more number of males is visiting to malls in comparison to females.

Table 5. Educational Qualification

\begin{tabular}{|c|c|c|c|}
\hline & Frequency & Percentage & Cumulative percentage \\
\hline \multirow{8}{*}{$\begin{array}{l}\text { None } \\
\text { Matriculation } \\
\text { Diploma } \\
\text { Degree } \\
\text { Master degree } \\
\text { Ph. d } \\
\text { Others } \\
\text { Total }\end{array}$} & 06 & 1.1 & 1.1 \\
\hline & 26 & 4.8 & 5.9 \\
\hline & 60 & 11.1 & 17.0 \\
\hline & 206 & 38.1 & 55.2 \\
\hline & 200 & 37.0 & 92.2 \\
\hline & 14 & 2.6 & 94.8 \\
\hline & 28 & 5.2 & 100.0 \\
\hline & 540 & 100.0 & \\
\hline
\end{tabular}

In the table number 5, it is found that 206 respondents are graduates and it is further followed by 200 respondents having master degree and 60 are diploma holders. So it can be concluded that large number of respondents are graduates and postgraduates in their qualification. Hence from this we can say that most of the respondents are highly qualified in nature.

\subsection{Inferential Statistics of Data Analysis}


Table 6. Anova Across Service Quality Aspects

\begin{tabular}{|c|c|c|c|c|c|c|}
\hline & & $\begin{array}{l}\text { Sum of } \\
\text { Squares }\end{array}$ & df & \begin{tabular}{c|} 
Mean \\
Square
\end{tabular} & $\mathrm{F}$ & Sig. \\
\hline \multirow[t]{3}{*}{$\begin{array}{l}\text { Materials associated with this outlet service (such as } \\
\text { shopping bags) are virtually appealing }\end{array}$} & $\begin{array}{l}\text { Between } \\
\text { Groups }\end{array}$ & 7.586 & 2 & 3.793 & 3.328 & .037 \\
\hline & $\begin{array}{l}\text { Within } \\
\text { Groups }\end{array}$ & 611.989 & 537 & 1.140 & & \\
\hline & Total & 619.576 & 539 & & & \\
\hline \multirow[t]{3}{*}{$\begin{array}{l}\text { The layout at this outlet makes it easier for me to find } \\
\text { what I need }\end{array}$} & $\begin{array}{l}\text { Between } \\
\text { Groups } \\
\end{array}$ & 19.078 & 2 & 9.539 & 6.602 & .001 \\
\hline & $\begin{array}{l}\text { Within } \\
\text { Groups } \\
\end{array}$ & 775.905 & 537 & 1.445 & & \\
\hline & Total & 794.983 & 539 & & & \\
\hline \multirow[t]{3}{*}{$\begin{array}{l}\text { The store layout makes it easier to move around in the } \\
\text { store }\end{array}$} & $\begin{array}{l}\text { Between } \\
\text { Groups }\end{array}$ & 9.225 & 2 & 4.612 & 3.871 & .021 \\
\hline & $\begin{array}{l}\text { Within } \\
\text { Groups } \\
\end{array}$ & 639.906 & 537 & 1.192 & & \\
\hline & Total & 649.131 & 539 & & & \\
\hline \multirow[t]{3}{*}{$\begin{array}{l}\text { Employees in this outlet respond to customer's requests } \\
\text { immediately }\end{array}$} & $\begin{array}{l}\text { Between } \\
\text { Groups } \\
\end{array}$ & 9.375 & 2 & 4.687 & 4.022 & .018 \\
\hline & $\begin{array}{l}\text { Within } \\
\text { Groups }\end{array}$ & 619.963 & 532 & 1.165 & & \\
\hline & Total & 629.338 & 534 & & & \\
\hline \multirow[t]{3}{*}{ The outlet gives customers individual attention } & $\begin{array}{l}\text { Between } \\
\text { Groups } \\
\end{array}$ & 10.657 & 2 & 5.328 & 4.322 & .014 \\
\hline & $\begin{array}{l}\text { Within } \\
\text { Groups } \\
\end{array}$ & 653.373 & 530 & 1.233 & & \\
\hline & Total & 664.030 & 532 & & & \\
\hline \multirow[t]{3}{*}{$\begin{array}{l}\text { Employees in this outlet are able to handle customer } \\
\text { complaints directly and immediately }\end{array}$} & $\begin{array}{l}\text { Between } \\
\text { Groups } \\
\end{array}$ & 8.054 & 2 & 4.027 & 3.511 & .031 \\
\hline & $\begin{array}{l}\text { Within } \\
\text { Groups }\end{array}$ & 615.880 & 537 & 1.147 & & \\
\hline & Total & 623.933 & 539 & & & \\
\hline \multirow[t]{3}{*}{ The outlet offers high quality merchandise } & $\begin{array}{l}\text { Between } \\
\text { Groups } \\
\end{array}$ & 8.085 & 2 & 4.043 & 3.528 & .030 \\
\hline & $\begin{array}{l}\text { Within } \\
\text { Groups }\end{array}$ & 595.788 & 520 & 1.146 & & \\
\hline & Total & 603.874 & 522 & & & \\
\hline \multirow[t]{3}{*}{$\begin{array}{l}\text { The outlet provides plenty of convenient parking for the } \\
\text { customers }\end{array}$} & $\begin{array}{l}\text { Between } \\
\text { Groups }\end{array}$ & 12.590 & 2 & 6.295 & 4.049 & .018 \\
\hline & $\begin{array}{l}\text { Within } \\
\text { Groups }\end{array}$ & 819.298 & 527 & 1.555 & & \\
\hline & Total & 831.889 & 529 & & & \\
\hline
\end{tabular}

In the above table 6, it is found that there exists a significant difference in many aspects of service quality across the three states. It is found that there exists a significant difference in the outlet services offered by various retail stores. It is also found that layout also differs across the different regions. There also exists a significant difference among the layout within the store also across the different regions. There also exists a significant difference in solving the customer problems. It is also found that there exists a significant difference towards solving the individual customer problem. It is also found that Employees differ in handling the customer's complaints directly and immediately. The table shows that outlets differ in quality merchandise 
and convenient parking for the customer in different regions.

Table 7. Anova Across Customer Satisfaction Aspects

\begin{tabular}{|c|c|c|c|c|c|c|}
\hline \multirow{4}{*}{$\begin{array}{l}\text { I am satisfied with my personal } \\
\text { contact with } \\
\text { the staff }\end{array}$} & & Sum of Squares & Df & Mean Square & $\mathrm{F}$ & Sig. \\
\hline & Between Groups & 4.871 & 2 & 2.435 & 3.50 & .031 \\
\hline & Within Groups & 369.660 & 532 & .695 & & \\
\hline & Total & 374.531 & 534 & & & \\
\hline
\end{tabular}

In the table number 7, it is found that customer's satisfaction level differs across the different states in personal contact with the staff. There exists a significant difference in personal contact of the staff with the customers across the different states.

Table 8. Anova Across Behavioral Aspects

\begin{tabular}{|c|c|c|c|c|c|c|}
\hline \multirow{2}{*}{$\begin{array}{c}\text { I would like to continue with this outlet even if the } \\
\text { store increases the prices of its products }\end{array}$} & $\begin{array}{c}\text { Between } \\
\text { Groups }\end{array}$ & 10.384 & 2 & 5.192 & 3.025 & .049 \\
\cline { 2 - 7 } & $\begin{array}{c}\text { Within } \\
\text { Groups }\end{array}$ & 906.294 & 528 & 1.716 & Sig. \\
\cline { 2 - 7 } & Total & 916.678 & 530 & & Mean \\
Square
\end{tabular}

In the table number 1.7 shows a significant different across the different regions in loyalty intentions of the customers towards a particular retail store. It is further found that there exists a significant difference in customer loyalty with the retail store when the retailer increases the prices of the products.

\section{Findings and Suggestions of the Study}

The main findings and suggestions of the study are as follows.

1. A total sample size of 540 Respondents are chosen from these three states. It is found that $184(34 \%)$ respondents belong to Delhi, 180 (33.3\%) respondents are from Haryana and 176 (32.6\%) from U.P. This shows the respondents distribution across the three states of India.

2. It is found that 230 respondents are belonging to 25 -to-35 years of age out of total 540 respondents. It is further followed by 138 respondents in the age category of 20-to-25 years. From the table it is also found that 88 people are above 45 years of age. So from the above analysis, it can be suggested that most of the respondents are falling in the age groups of 25-to-35 years of age.

3. It is found that there are 540 respondents in the table. It is found that there are 343 female and 197 male in the total sample.

4. It is found that 206 respondents are graduates and it is further followed by 200 respondents having master degree and 60 are diploma holders. So it can be concluded that large number of respondents are graduates and postgraduates in their qualification. Hence from this we can say that most of the respondents are highly qualified in nature.

5. It is found that there exists a significant difference in many aspects of service quality across 
the three states. It is found that there exists a significant difference in the outlet services offered by various retail stores. It is also found that layout also differs across the different regions. There also exists a significant difference among the layout within the store also across the different regions. There also exists a significant difference in solving the customer problems. It is also found that there exists a significant difference towards solving the individual customer problem. It is also found that Employees differ in handling the customer's complaints directly and immediately. The table shows that outlets differ in quality merchandise and convenient parking for the customer in different regions.

6. It is found that customer's satisfaction level differs across the different states in personal contact with the staff.

7. It shows a significant different across the different regions in loyalty intentions of the customers towards a particular retail store. It is further found that there exists a significant difference in customer loyalty with the retail store when the retailer increases the prices of the products.

\section{Conclusion of the Study}

From the conclusion of the study we can say that there exist significant differences in many aspects of service quality in three different states of the country. From the above discussion of results the significant differences are found in outlet services offered by various retail stores as well as in that layout also across the different regions. It is also found that there exists a significant difference among the layout within the store in the different regions and difference in solving the customer problems. Hence we can conclude that customers have different opinions towards the aspects of service quality across the different regions. It is also found that there exists a significant difference towards solving the individual customer problem. In further analysis it is found that customer satisfaction also differs across the different regions. Hence from this we can say that marketers should change their strategies from place to place to satisfy the customer needs. Another conclusion is that employees are not having the equal skills and knowledge to deal with the customer problems across the different regions. Hence it is important to impart the skills and knowledge to the employees in a manner so that they can solve the customer problems easily. From the above study it is also found that customer purchasing as well as recommending decisions differ from place to place. So it becomes important for the marketer to understand the customer behavioral aspects across the different regions and accordingly they need to serve the customers in that particular region.

\section{References}

Boulding, W., Kalra, A., Staelin, R., \& Zeithaml, V. A. (1993). A dynamic process model of service quality: from expectations to behavioral intentions, Journal of Marketing Research, Vol. 30, February, pp. 7-27. http://dx.doi.org/10.2307/3172510

Cronin, J. J. Jr \& Taylor, S. A. (1992). Measuring service quality: a re-examination and Extension, Journal of Marketing, Vol. 56, July, pp. 55-68. http://dx.doi.org/10.2307/1252296

Greising, D. (1994). Quality: how to make it pay, Business Week, 8 August, pp. 54-9. 


\section{Al Macrothink}

Business and Economic Research ISSN 2162-4860 2014, Vol. 4, No. 2

Hardesty, David M., \& William O. Bearden (2003). Consumer Evaluations of Different Promotion Types and Price Presentations: The Moderating Role of Promotional Benefit Level, Journal of Retailing, 79(1), 17-25. http://dx.doi.org/10.1016/S0022-4359(03)00004-6

Hardesty, David M., William O. Bearden \& Jay P. Carlson (2007). Persuasionn Knowledge and Consumer Reactions to Pricing Tactics, Journal of Retailing, 83(2), 199-210. http://dx.doi.org/10.1016/j.jretai.2006.06.003

Indian Retail Report, 2009.

Keaveney, S. M. (1995). Customer switching behaviour in service industries: an exploratory study, Journal of Marketing, Vol. 59, April, pp. 71-82. http://dx.doi.org/10.2307/1252074

Netemeyer, Richard G., Balaji Krishnan, Chris Pullig, Guangping Wang, MehmetYagci, Dwane Dean, Joe Ricks \& FerdinandWirth (2004). Developing and Validating Measures of Facets of Customer-Based Brand Equity, Journal of Business Research, 57(February), 209-24. http://dx.doi.org/10.1016/S0148-2963(01)00303-4

Park, C-H., \& Kim, Y. G., (2003). Identifying key factors affecting consumer purchase behavior in an online shopping context. International Journal of Retail and Distribution Management 30(1), 16-29. http://dx.doi.org/10.1108/09590550310457818

Reichheld, F. F., \& Schefter, P., (2000). E-loyalty your secret weapon on the Web. Harvard Business Review. 78(4), 105-113.

Rust, R. T., Zahorik, A. J., \& Keiningham, T. L. (1995). Return on quality (ROQ): making service quality financially accountable, Journal of Marketing, Vol. 59, April, pp. 58-70. http://dx.doi.org/10.2307/1252073

Singh Ajmer (2012). Impact of Perceived Service Quality on Customer Loyalty Intentions in Retail Outlets. European Journal of Business Management, 4(21), 138-149. (ISSN: 2222-2839)

Singh Ajmer (2013). Comparison of Service Quality, Customer Satisfaction and Behavioral intentions across the Various Formats (Supermarket, Hypermarket \& Departmental Store) in India. Business and Economics Research, 3(1), 344-355. (ISSN: 2162-4860). http://dx.doi.org/10.5296/ber.v3i1.3443

Singh Ajmer (2013). Relationship between Service Quality and Customer Satisfaction in Organized Retail Outlets. Developing Country Studies, 3(1), 84-95. (ISSN: 2225-0565)

Spreng, R. A., MacKenzie, S. B., \& Olshavsky, R. W. (1996). A re-examination of the determinants of consumer satisfaction, Journal of Marketing, Vol. 60, July, pp. 15-32. http://dx.doi.org/10.2307/1251839

Taguiri, R., \& Davis, J. A., (1992). On the goals of successful family companies. Family Business Review. 5(1), 263-281.

Yang, Z., \& Peterson, R. T., (2004). Customer perceived value, satisfaction, and loyalty: the role of switching costs. Psychology \& Marketing. 21(10), 799-822. 


\section{Macrothink}

Business and Economic Research

ISSN 2162-4860

2014, Vol. 4, No. 2

http://dx.doi.org/10.1002/mar.20030

\section{Copyright Disclaimer}

Copyright for this article is retained by the author(s), with first publication rights granted to the journal.

This is an open-access article distributed under the terms and conditions of the Creative Commons Attribution license (http://creativecommons.org/licenses/by/3.0/). 